U.S. Department of the Interior

U.S. Geological Survey

\title{
Lahar Hazards at Concepción Volcano, Nicaragua
}

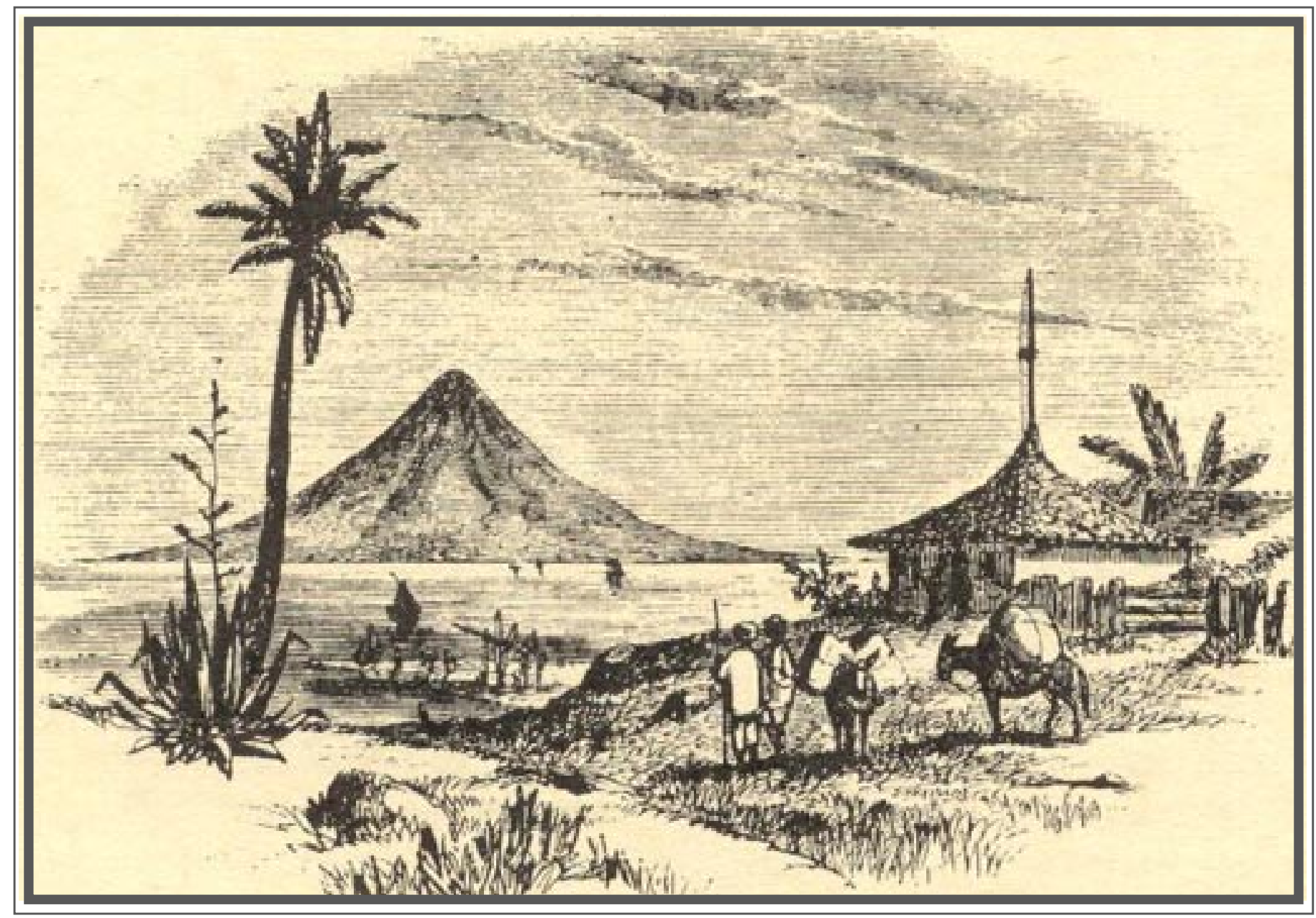

Open-File Report 01-457

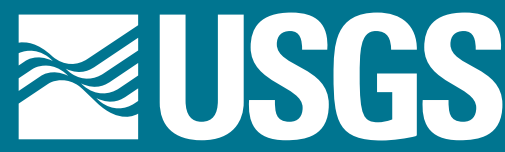




\section{Cover photograph}

Lithograph showing Lake Nicaragua and Concepcion Volcano adapted from Squier (1856). 


\section{Lahar Hazards at Concepción Volcano, Nicaragua}

By J.W. Vallance, S.P. Schilling, G. Devoli, and M.M Howell

U.S. GEOLOGICAL SURVEY

Open-File Report 01-457

Vancouver, Washington U.S.A. 


\section{U.S. DEPARTMENT OF THE INTERIOR \\ Gale Norton, Secretary}

\section{U.S. GEOLOGICAL SURVEY}

Charles G. Groat, Director

This report is preliminary and has not been reviewed for conformity with U.S. Geological Survey editorial standards. Any use of trade, product, or firm names is for descriptive purposes only and does not imply endorsement by the U.S. Government.

Scientist-in-Charge

U.S. Geological Survey

1300 SE Cardinal Court, Bldg. 10

Vancouver, WA 98683

(360) $993-8900$

FAX: (360) 993-8980
U.S. Geological Survey

Information Services

P.0. Box 25286

Denver, CO 80225

(303) 202-4210 


\section{CONTENTS}

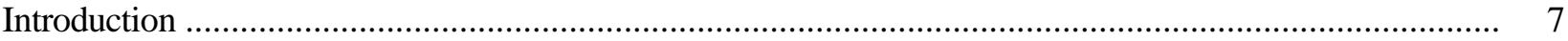

Debris Avalanches, Landslides, and Lahars …............................................................................ 9

Future Landslides and Lahars at Concepción Volcano ........................................................................ 10

Lahar-Hazard-Zonation Map ................................................................................................... 10

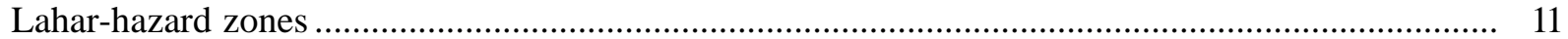

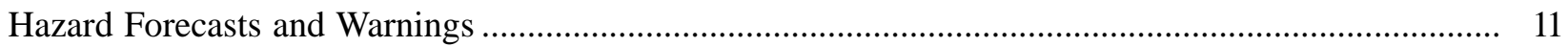

Protecting Communities and Citizens from Lahar Hazards ...................................................... 11

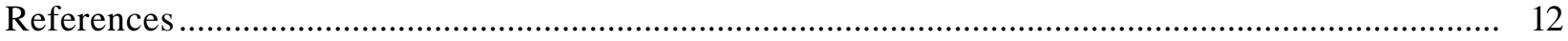

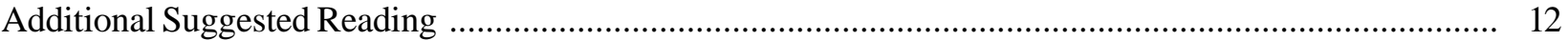

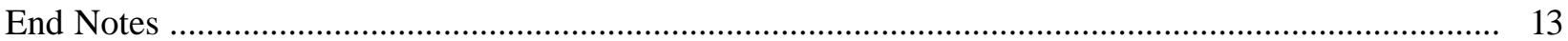

\section{PLATE [In pocket]}

1. Lahar hazards of Concepción volcano, Nicaragua. Proximal and distal hazard zones from lahars at Concepción volcano.

\section{FIGURES}

1. Locations of major cities and significant Quaternary volcanoes in Nicaragua including Concepción volcano and schematic map showing the areal extent of and two crosssections for the Casita, Nicaragua debris flow of 1998 



\title{
Lahar Hazards at Concepción Volcano, Nicaragua
}

\author{
By J.W. Vallance, S.P. Schilling, G. Devoli' and M.M. Howell
}

\section{INTRODUCTION}

Concepción is one of Nicaragua's highest and most active volcanoes [1] (numerals in brackets refer to end notes in the report). The symmetrical cone occupies the northeastern half of a dumbbellshaped island called Isla Ometepa. The dormant volcano, Maderas, occupies the southwest half of the island (figure 1). A narrow isthmus connects Concepción and Maderas volcanoes. Concepción volcano towers more than $1600 \mathrm{~m}$ above Lake Nicaragua (figure 1) and is within 5 to $10 \mathrm{~km}$ of several small towns situated on its aprons at or near the shoreline. These towns have a combined population of nearly 5,000. The volcano has frequently produced debris flows (watery flows of mud, rock, and debris-also known as lahars when they occur on a volcano) that could inundate these nearby populated areas.

Concepción volcano has erupted more than 25 times in the last 120 years [1]. Its first recorded activity was in AD 1883. Eruptions in the past century, most of which have originated from a small summit crater, comprise moderate explosions, ash that falls out of eruption plumes (called tephra), and occasional lava flows. Near the summit area, there are accumulations of rock that were emplaced hot (pyroclastic deposits), most of which were hot enough to stick together during deposition (a process called welding).
These pyroclastic rocks are rather weak, and tend to break apart easily. The loose volcanic rock remobilizes during heavy rain to form lahars. Volcanic explosions have produced blankets of tephra that are distributed downwind, which on Isla Ometepe is mostly to the west. Older deposits at the west end of the island that are up to $1 \mathrm{~m}$ thick indicate larger explosive events have happened at Concepción volcano in prehistoric time. Like pyroclastic-flow deposits, loose tephra on the steep slopes of the volcano provides source material that heavy rainstorms and earthquakes can mobilize to trigger debris flow.

North-south-trending fractures cutting across the volcano are associated with small volcanic flank vents called spatter cones, cinder cones, and maars located on the middle north flank and on the lower south flank of Concepción volcano down to Lake Nicaragua [1]. Immature soils on deposits of fine ash to the west of these vents show that several of them have been active within recent prehistoric time.

In late October and early November 1998, torrential rains of Hurricane Mitch caused numerous slope failures in Central America, the most catastrophic of which occurred at Casita volcano, Nicaragua on October 30, 1998. At Casita, five days of heavy rain triggered a 1.6-million-cubic-meter rock and debris avalanche

${ }^{1}$ Instituto Nicaragüense de Estudios Territoriales (INETER), Managua, Nicaragua. 


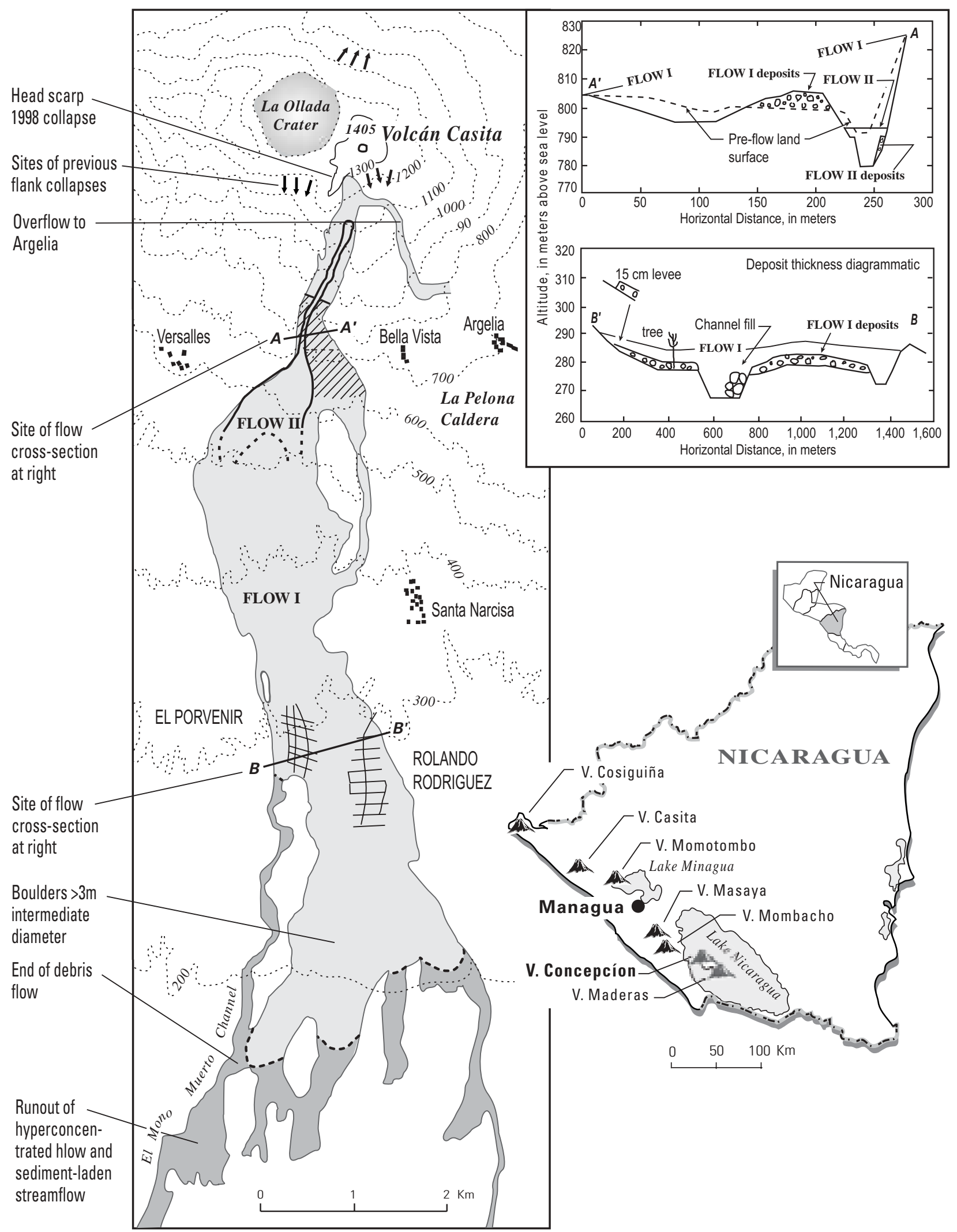

Figure 1. Locations of major cities and significant Quaternary volcanoes in Nicaragua including Concepción volcano and schematic map showing the areal extent of and two cross-sections for the Casita, Nicaragua debris flow of 1998 adapted from Scott $e t$ al. (in press). 
that generated a 2- to 4-million-cubic-meter debris flow that swept down the steep slopes of the volcano, spread out across the volcano's apron, destroyed two towns, and killed more than 2500 people [2]. The avalanche did not dam the upper drainages or impound water. Rather, it appears that the Casita debris flow evolved directly as the avalanche moved down slope [2].

On October 30, 1998 between 10:30 and 11:00 AM, residents south of Casita heard a roaring noise like helicopters or thunder. Some thought an earthquake was occurring. Three to five minutes thereafter, a wave of muddy debris $1.0-1.3 \mathrm{~km}$ wide and an average of $3.5 \mathrm{~m}$ deep destroyed all traces of two towns (figure 1). Observations by survivors record an enormous flood on the slopes of the volcano and a wall of mud on the volcano apron. A person on the volcano slopes saw a "black curtain of water with trees." On the apron of the volcano where the flow spread out, survivors describe the flow as, "an infernal wave of mud, rocks, and trees," or, "an enormous mass of mud." [2]. The debris flow moved about $10 \mathrm{~km}$ from its source. It also generated floods that moved an additional $10 \mathrm{~km}$ downstream, destroying roads and bridges and inundating homes.

Small debris flows occurred at Concepción volcano during Hurricane Mitch but none so large as the one that occurred at Casita. The largest is more than an order of magnitude smaller than the Casita debris flow. It descended SSW about $5 \mathrm{~km}$ toward San José del Sur (plate 1). A note in BVGN in March 1993 indicates that the area to the North and the SSW gully are the main foci of lahars in the recent past [1]. Deposits suggest that all of these lahars are similar in size and at least an order of magnitude smaller than that at Casita in 1998.

Lahars continue to form during rainstorms, with the main loci of activity being the $S W$ gully and the $N$ flank. The road $N$ of the volcano was cut by a lahar in late 1992. Erosion remains rapid on higher slopes, where some gullies had widened by $2-5 \mathrm{~m}$ since 1990. The 1957/74 pyroclastic deposits are especially vulnerable to erosion and gully headwalls have almost intersected the crater rim to the $N, W$, and $S W$ in the last two years. Rapid erosion of these deposits probably constitutes much of the source for the laharic material to the $N$ and $W$ of the cone. The towns of San Jose del Sur $(6.2 \mathrm{~km}$ SSW), San Marcos (5.6 km NNW), and La Flor $(5.3 \mathrm{~km} \mathrm{NW})$ are in a particularly dangerous situation because they are in the paths of lahars descending these gullies. [1].

Several very active, young symmetrical volcanoes in Nicaragua seem not to be as susceptible to slope failures as large as the one that occurred at Casita during Hurricane Mitch. San Cristóbal, Telica, Momotombo and Concepción volcanoes are all young, symmetrical cones that are formed of fresh rock. During Hurricane Mitch, small lahars and floods occurred at these volcanoes but none approaching the size of the big Casita flow. In contrast, Casita volcano is an older edifice where alteration processes have locally affected the rocks and where erosion has deeply incised its slopes. Alteration and erosion both weaken the edifice, making it more susceptible to failure.

Volcanoes emit gases that react with water to make acid, especially sulfuric acid. These acidic waters then react with the rocks to weaken them. With time the above hydrothermal processes weaken older volcanic edifices and make them more susceptible to landslides. Rain-induced landslides in altered, weakened rock are apt to form large lahars.

This report describes the hazards of landslides and lahars in general, and discusses potential hazards from future landslides and lahars at Concepción volcano in particular. The report also shows, in the accompanying lahar-hazard-zonation map, which areas are likely to be at risk from future landslides and lahars at Concepción. For a broader volcano-hazard assessment of the volcano see references in end note [1].

\section{DEBRIS AVALANCHES, LANDSLIDES, AND LAHARS}

Slope failure on a volcano can generate a rapidly moving landslide called a debris avalanche. Small-volume debris avalanches typically travel only a few kilometers from their 
source, but large-volume debris avalanches can travel tens of kilometers from their source. Debris avalanches destroy everything in their paths and can leave deposits of 10 meters thick or more on valley floors.

Lahars, also called mudflows and debris flows, are masses of mud, rock, and water that look much like flowing concrete. They occur when water mobilizes large volumes of loose mud, rock, and volcanic debris. Commonly, landslides and debris avalanches will incorporate enough water to form lahars. Lahars, like floods, inundate floodplains and structures in low-lying areas. They can travel many tens of kilometers down valleys at speeds of tens of kilometers per hour. Lahars destroy or damage everything in their paths through burial or impact. Lahars follow river valleys and leave deposits of muddy sand and gravel that can be several meters thick. They are particularly hazardous because they travel farther from a volcano than any other hazardous phenomenon except tephra, and they affect stream valleys where human settlement is usually greatest. In some instances, lahars clog channels or block tributaries so that water collects behind the blockage. The impounded water can spill over the blockage and generate floods that move down valley. Breaching of such blockages can occur within hours, months, or even years after impoundment.

Like floods, lahars range greatly in size. The smallest lahars occur most frequently (perhaps every few years), whereas the largest recur on the order of centuries to millennia. The amount of water and loose volcanic debris entrained determines lahar size. Eruptions can deposit millions of cubic meters of sediment into channels that when mixed with water during subsequent rains causes lahars.

Landslides and lahars can cause problems long after the original eruption or other disturbance. Once lahars fill stream channels with sediment, the streams begin to erode new paths. The new stream channels can be highly unstable and shift rapidly as sediment is eroded and moved farther down valley. Also, because stream channels are clogged with sediment, they have less ability to convey water and thus are more susceptible to smaller-magnitude floods.

\section{FUTURE LANDSLIDES AND LAHARS AT CONCEPCIÓN VOLCANO}

Concepción volcano can erupt explosively to produce pyroclastic deposits and widespread tephra falls. The lack of historical volcanism of this type suggests that the probability of explosive eruptions at Concepción is less than once every two hundred years. The ash and loose debris produced by an eruption would surely cause lahars when mixed with water from rains during the rainy season. Small volcanic earthquakes, steam explosions and deformation of the crater area would be likely to precede pyroclastic eruptions at Concepción volcano

Because frequent eruptions are likely to replenish loose sediment in steep barrancas that incise the slopes of Concepción volcano, landslides and debris flows during torrential rainstorms are the most likely threats to nearby people and infrastructure [1]. These phenomena, like those at Casita, are most apt to occur during unusually intense rain. Because loose sediment can collect during eruptions or long dry periods and because water can easily mobilize that sediment, lahars are especially likely during the first rains after eruptions, at the beginning of the rainy season.

\section{LAHAR-HAZARD-ZONATION MAP}

The accompanying lahar-hazard-zonation map (plate 1) shows areas that could be affected by future lahars at or near Concepción volcano. Individual lahars typically affect only part of a hazard zone. The location and size of an affected area will depend on local conditions, such as the volume of material involved, and the size and character of an eruption, if any.

Lahar-hazard zones are subdivided on the basis of their relative degree of hazard. Hazardzone boundaries derive from three main factors. First, there are the magnitudes of lahars known to have occurred at the volcano, as inferred from historical accounts and prehistoric deposits. Second, an empirical model calibrates laharinundation limits on the basis of lahars of known volume that have occurred at other volcanoes. Third, we apply our experience and judgment 
derived from past experience with events of a similar nature at other volcanoes.

Although sharp boundaries delineate each hazard zone, the limit of the hazard does not end abruptly at the boundaries. Rather, the hazard decreases gradually with increasing distance from the volcano and decreases rapidly with increasing elevation above valley floors. Areas immediately beyond distal hazard zones are not free of risk because the hazard limits can be located only approximately, especially in areas of low relief. Many uncertainties about the source, size, and mobility of future lahars preclude precise determination of the hazard-zone boundaries.

Users of our hazard map should be aware that we have not simulated all hazardous landslide and lahar scenarios. The edifice of Concepción volcano is very steep and incised. For this report, we selected prominent channels directed toward populous areas in order to define the most significant zones of inundation from lahars of various volumes. Other channels for which we have not modeled lahar inundation are not necessarily devoid of lahar hazard. Landslides and lahars from other unmapped channels could also threaten life and property.

\section{Lahar-hazard zones}

An automated empirical technique calibrated with data from other volcanoes [3] estimates potential areas of inundation from lahars of various volumes. For each channel analyzed, we define four nested hazard zones that depict anticipated inundation by hypothetical "design" lahars having different volumes. The largest design lahar (volume, 1 million cubic meters) reflects our estimate of the largest probable lahar generated on the steep slopes of Concepción volcano (plate 1) [3]. The intermediate and smallest design lahars $(125,000,250,000$, and 500,000 cubic meters) are more typical lahar volumes. Lahars of the largest size have occurred historically at Concepción and would be most likely after an eruption or during severe rainstorms.

Large lahars are less likely to occur than small lahars. Thus, the nested lahar-hazard inundation zones show that the likelihood of lahar inundation decreases as distance from the volcano and elevation above the valley floors increases. Lahars of all designated sizes could form on the volcano's slopes if unusually intense rainstorms occur. An intense storm, like Hurricane Mitch, would not invariably trigger lahars as large as the largest model lahars. Smaller lahars may occasionally result from heavy rains that normally occur each year during the rainy season of May to November.

In general, lahar-hazard zones extend 5 to 8 kilometers from the summit crater (plate 1). Local topography is similar on all sides of the volcano, so lahar travel distances are comparible on each side. Despite their relatively short runout distances, even the smallest lahars moving northward or southsouthwestward can be devastating because of nearby population centers in those directions.

\section{HAZARD FORECASTS AND WARNINGS}

It is difficult, if not impossible, to predict the precise occurrence of landslides and lahars triggered by earthquakes or torrential rains. However, generally hazardous conditions that favor formation of landslides and lahars can be recognized. Forecasts for very heavy rainfall, which commonly trigger flood warnings, can serve as indicators of conditions favorable for landslides and lahars. When Concepción volcano erupts again, it is likely to disperse tephra fall on its flanks. Subsequent erosion of that tephra can generate lahars similar to or larger than those that have occurred in historical time. Eruption of the volcano can serve as a warning that conditions are favorable for lahar formation. The distribution of tephra fall can indicate which flanks are more likely to be inundated by lahars. However, government officials and the public need to realize that potentially lethal events can occur in the lahar hazard zones with little or no warning.

\section{PROTECTING COMMUNITIES AND CITIZENS FROM LAHAR HAZARDS}

Communities and citizens must plan ahead to mitigate the effects of future landslides and lahars from Concepción volcano. Long-term mitigation 
efforts might include using information about lahar and other volcano hazards contained in plate 1 when making decisions about land use and siting critical facilities and development. Future development should avoid areas judged to have an unacceptably high risk.

Because the volcano is on a small island, the hazard zones depicted on the map are areas that will be affected within a few minutes after the onset of a lahar. If precursors provide people with sufficient warning that they are at risk, the only action possible is to move to high ground away from barrancas that funnel onto the apron of the volcano. Because most of the island is within 10 kilometers of the volcano, lahars may reach populated areas before officials can provide notification. Furthermore, lahars can block roads and preclude escape from the island by way of the main port of Moyogalpa. Therefore, citizens must learn to recognize for themselves hazardous conditions that favor formation of landslides and lahars, such as volcanic eruptions, the first rains after eruptions, and unusually intense rainfall, especially at the onset of the rainy season. When conditions favor lahars, inhabitants should be aware that a sound like that of an approaching freight train may signal an approaching lahar.

Because landslides and lahars can occur without warning, suitable emergency plans for dealing with them should be made in advance. Although it is uncertain when landslides and lahars will occur again at Concepción volcano, public officials need to consider issues such as public education, communications, and evacuations as part of a response plan. Emergency plans already developed for floods may apply to some extent, but may need modifications. For inhabitants in low-lying areas a map showing the shortest route to high ground would be helpful.

Knowledge and advance planning are the most important items for dealing with landslide and lahar hazards. Especially important is a plan of action based on the knowledge of relatively safe areas around homes, schools, and workplaces. Lahars pose the biggest threat to people living or recreating along channels that drain Concepción volcano. The best strategy for avoiding a lahar is to move to the highest possible ground. A safe height above river channels depends on many factors including the size of the lahar, distance from the volcano, and shape of the valley.

Landslides and lahars from Concepción volcano will happen again, and the best way to cope with these events is through advance planning in order to mitigate their effects.

\section{REFERENCES}

Borgia, A., van Wyk de Vries, B, and Baxter, P, 1993, Detailed description of crater, Concepción: Global Volcanism Newsletter, Smithsonian Institute, March 1993

Iverson, R.M., Schilling, S.P., and Vallance, J.W., 1998, Objective delineation of lahar-hazard zones downstream from volcanoes: Geological Society of America Bulletin, v. 110, p. 972-984.

Kerle, N., in press, Volume estimation of the 1998 flank collapse at Casita volcano, a comparison of photogrammetric and conventional techniques: Earth Surface Processes and Landforms

Kerle, N., and van Wyk de Vries, B., 2001, The 1998 debris avalanche at Casita volcano, investigation of structural deformation as the cause of slope instability using remote sensing: Journal of Volcanology and Geothermal Research, v. 105, p. 43-63.

Scott, K.M., Vallance, J.W., Kerle, N, Macías, J.L., Strauch, W., Devoli, G., in press, Catastrophic, precipitation-triggered lahar at Casita volcano, NicarConcepción-Flow transformations, flow bulking, and future mitigation stratigies.

Sheridan, M.F., Bonnard, C., Carreno, R., Siebe, C., Strauch, W., Navarro, M., Calero, J.C., and Trujillo, N.B., 1999, Report on the 30 October 1998 rockfall/debris avalanche and breakout flow of Casita volcano, triggered by Hurricane Mitch: Landslide News, n. 12, p. 2-4.

van Wyk de Vries, B, 1987, Volcanic hazards of Isla de Ometepe Lago de Nicaragua: Unpublished report for INETER, $38 \mathrm{p}$.

\section{ADDITIONAL SUGGESTED READING}

Blong, R.J., 1984, Volcanic hazards: Academic Press, Orlando, $424 \mathrm{p}$.

Tilling, R.I., ed., 1989, Volcanic hazards: Short course in geology, v. 1, American Geophysical Union, Washington, D.C., 123 p. 
Vallance, J.W. 2000, Lahars: in Sigurdsson, H., Houghton, B., McNutt, S., Rymer, H., and Stix, J., Encyclopedia of Volcanoes, Academic Press, San Diego, p. 601-616.

\section{END NOTES}

[1] Vocano hazard assessments at Concepción can be found in van Wyk de Vries (1987). Other geologic data upon which this report is based come chiefly from the Borgia et al. (1993) and van Wyk de Vries (1987).

[2] Information about the Casita flow derives from Sheridan et al. (1999), Kerle and van Wyk de Vries (2001), Kerle (in press), and Scott et al. (in press).
[3] We constructed lahar-hazard zones by choosing design-lahar volumes of 125,000; 250,000; 500,000; and 1,000,000 cubic meters. We then modeled a lahar for each volume using the repeatable empirical model and digital cartographic technique described in Iverson et al. (1998). The model requires the choice of a reasonable range of volumes for each volcano. It then uses these volumes to compute average cross-sectional areas and areas of inundation for each modeled lahar. The GIS based computer program, LAHARZ (Iverson et al., 1998) then calculates the extent of inundation downstream in each drainage that heads on the volcano. 


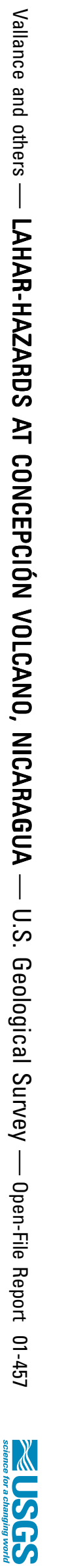

8 Printed on recycled paper 